УДК: 321.7

https://doi.org/10.34142/24130060.2019.18.2.08

\title{
ДЕМОКРАТИЗАЦІЯ СУСПІЛЬСТВА ЯК ОСНОВА ДЕМОКРАТИЗАЦІЇ ВЛАДИ: ТЕОРЕТИКО-МЕТОДОЛОГІЧНІ ПІДХОДИ
}

\author{
I.B. Застава \\ Харківський національний університет імені В.Н. Каразіна
}

\begin{abstract}
Проаналізовано та узагальнено теоретико-методологічних підходів щуодо демократизації суспільно-політичних відносин як основи демократизації влади. Розглянуто ключові питання впливу сформованих суспільно-політичних цінностей на розвиток демократії. Визначено, що демократизація - необхідна передумова розвитку духовної культури, всебічного розповсюдження духовного прочесу, де акцент робиться на обізнаності культури загальнолюдських иінностей, ідеалів та принципів. Обтрунтовано, щзо демократизація суспільно-політичних відносин сприятиме задоволенню потреб $i$ інтересів громадян та призведе до підвищення авторитету як владних структур, так $i$ інститутів громадянського суспільства. Для вдосконалення процесу демократизації суспільно-політичних відносин необхідно розвивати та стимулювати формування ключових демократичних цінностей, таких як: професіоналізм керівників урядів на різних рівнях влади; ефективність, підзвітність гілок влади; орієнтачія на соціальні потреби країни з урахуванням минулого історичного досвіду; відкрита, прозора, некорумпована та сочіально орієнтована система політичних відносин.
\end{abstract}

Ключові слова: демократія, демократизачія суспільства, демократизація влади, культура, свобода, вибори, опозиція, конкуренція, плюралізм.

\section{ДЕМОКРАТИЗАЦИЯ ОБЩЕСТВА КАК ОСНОВА ДЕМОКРАТИЗАЦИИ ВЛАСТИ}

\section{И.В. Застава}

Проанализированы и обобщены теоретико-методологические подходы к демократизачии общественно-политических отномений как основы демократизачии власти. Рассмотрены ключевые вопросы влияния сложившихся общественнополитических иенностей на развитие демократии. Определено, что демократизация необходимая предпосылка развития духовной культуры, всестороннего распространения духовного проиесса, где акиент делается на осведомленности культуры общечеловеческих иенностей, идеалов и принципов. Обосновано, что демократизация общественно-политических отношений будет способствовать удовлетворению потребностей и интересов граждан и приведет к повышению авторитета как властных структур, так и институтов гражданского общества. Для совершенствования прочесса демократизации общественно-политических отночений необходимо развивать и стимулировать формирование ключевых демократических ценностей, таких как: профессионализм руководителей правительств на различных уровнях власти; эффективность, подотчетность ветвей власти; ориентация на сочииальные нужды

(C) I.В. Застава, 2019 
страны с учетом прошлого исторического опьта; открытая, прозрачная, коррумпированная и социально ориентированная система политических отношений.

Ключевые слова: демократия, демократизащчия общуества, демократизациия власти, культура, свобода, выљоры, оппозицчия, конкуренция, плюрализм.

\section{DEMOCRATIZATION OF SOCIETY AS THE BASIS OF DEMOCRATIZATION OF POWER}

\section{Zastava}

The theoretical and methodological approaches to the democratization of socio-political relations as the basis for the democratization of power are analyzed and generalized. The key issues of the influence of prevailing socio-political values on the development of democracy are examined. It was determined that democratization is a necessary prerequisite for the development of spiritual culture, the comprehensive dissemination of the spiritual process, where the emphasis is on awareness of the culture of universal values, ideals and principles. It is proved that the democratization of socio-political relations will contribute to the satisfaction of the needs and interests of citizens and will lead to an increase in the authority of both power structures and civil society institutions. To improve the process of democratization of sociopolitical relations, it is necessary to develop and stimulate the formation of key democratic values, such as: professionalism of government leaders at various levels of government; efficiency, accountability of the branches of government; orientation to the social needs of the country, taking into account past historical experience; an open, transparent, corrupt and socially oriented system of political relations. The democratization of political life is not just about recognizing people as a source of political power, or affirming universal suffrage on equal terms, the emergence of multi-party politics, or declaring political rights and fundamental freedoms. Democratization determines the state of the individual's spiritual freedom, the measure of creativity and the creation of opportunities. The spiritual revival of a society in a democracy is a multifaceted process of forming a spiritual culture, based on the emphasis in society on the principles and ideals of democratic content, which creates an opportunity for the free development of all cultures, types, orientations and forms represented in this society. It is a tendency towards universal values and the specificity of its manifestations in the national identity, which ensures spiritual process and global development.

Keywords: democracy, democratization of society, democratization of power, culture, freedom, elections, opposition, competition, pluralism.

Постановка проблеми. За останні двадцять років інтерес дослідників до проблем демократизації різко зріс. Це пояснюється насамперед тим, що демократизація стає все більш багатонаціональним процесом, на який впливають багато чинників. На характер, форму та спрямованість демократичного транзиту впливають умови політичного, соціальнокультурного та соціально-економічного розвитку. Більше того, стає очевидним різноманітність моделі ліберальної демократії, яка не завжди демонструє свої переваги перед іншими системами регулювання влади, 3 практичним застосуванням у ряді національних держав (Куц, 2011, с. 26-30). 
Тим часом, в останні десятиліття трансформації від недемократичних форм правління настільки змінилися на індивідуальні в різних країнах, що жодна загальна логіка трансформації не може бути побудована і зведена до жодної моделі. Складно стверджувати про успішний висновок та формування єдиної демократії, оскільки процес демократизації часто є незавершеним.

Проблеми демократизації у політичній сфері життя громади та духовного відродження сьогодні є центральними у розвитку української держави. Демократизація - необхідна передумова розвитку духовної культури, всебічного розповсюдження духовного процесу, де акцент робиться на обізнаності культури загальнолюдських цінностей, ідеалів та принципів (Куц, 2018). Для узагальненого, комплексного дослідження передумов, умов демократизації, очевидним $є$ теоретико-методологічний синтез усіх підходів і рівнів аналізу до цього процесу. Тільки за цієї умови можна говорити про цілісний i систематизований опис та пояснення ключового моменту демократизації - встановлення демократичного політичного режиму і відповідних процедур.

Аналіз актуальних досліджень. Сучасні уявлення про демократизацію суспільства $€$ результатом їх тривалої еволюції в історії соціальнофілософської і політико-правової думки. Це пояснює їх різноманітність і суперечність. Проблему співвіднесення демократизації суспільства та демократизації влади вивчали такі автори, як Т. Карл, С. Ліпсет, А. Мельвіль, А. Пшеворський, Ф. Шміттер, С. Хантингтон та ін.

Метою статті $\epsilon$ - виявити яку роль демократизація суспільства відіграє у демократизаційному процесі, а саме у процесі демократизації влади.

Виклад основного матеріалу. Останнім часом поняття «демократія» є одним з найпопулярніших в політичному дискурсі. Воно використовується політичними теоретиками, аналітиками, публіцистами. 3 одного боку, це ідеал суспільно-політичного життя людства, універсальна мета політичного розвитку, з іншого самоназва політичних систем Заходу. Тобто, до сих пір так і не визначено однозначного сприйняття демократії та методології іiі 
дослідження. Існуючі на даний момент кілька теоретико-базових підходів конкурують між собою і висувають на перший план ті чи інші аспекти.

Зазначимо, що демократизація - процес впровадження демократичних принципів в політичну систему, культуру, стиль життя і т.д. (Грачев и Мадатов, 2004)

Демократизація суспільства означає, в першу чергу, руйнування старих інститутів в економічних відносинах, в соціальних відносинах між людьми, $\mathrm{i}$ реорганізацію політичної (державної) влади.

Немає чіткої відповіді на питання про фактори, що визначають напрямок та характер демократичного транзиту. Існують різні точки зору науковців на проблему зв’язку глобальних та локальних факторів у процесі демократизації. Пріоритет глобальних міжнародних факторів розвитку демократії підкреслювався дослідженнями наприкінці ХX століття. Так, А. Пшеворський підкреслював, що будь-яка демократизація - це інтернаціоналізація та прагнення публічно сприймати та розвивати імпульси у напрямку глобальних досягнень (Пшеворський, 1993).

С. Хантінгтон розглядає перехід до демократії як глобальний процес, згідно 3 яким кожну країну впливає глобальний демократичний рух (Хантингтон, 2003). Тим часом, дивлячись на масштабний демократичний транзит у другій половині 1970-х, автор наголошує на можливості створення різних форм демократичного порядку.

C. Хантінгтон зазначає, що процес демократизації став синусоїдальним, тому розглядає можливість зворотного руху (недемократичні та недемократичні тенденції) та «четвертої хвилі» демократизації. Ідея неминучого встановлення демократичної системи працює через червону лінію через усі дії С. Хантінгтона. Безпрецедентний глобальний ріст у 1960-х роках зміни політики діють на міжнародній арені (особливо Свропейське співтовариство, США та Радянський Союз), ефект демонстрації демократичних перетворень, підсилених новими засобами 
міжнародної комунікації, що грають каталітичну роль і слугують привабливою моделлю сучасних перетворень (Хантингтон, 2003).

А. Мелвіль зазначає, не зважаючи на фактори, а на динаміку внутрішніх компонентів демократизації, що майже всі сучасні демократичні транзити значною мірою $\epsilon$ внутрішнім результатом певних рішень та варіантів політичної тактики та стратегій ключових політичних суб'єктів, хоча є деякий зовнішній контекст у процесі демократизації (2007). М. Грачев та А. Мадатов у своїх дослідженнях з питань демократизації підтримують ідеї А. Мельвіля. На їхню думку, зовнішні фактори, безперечно, відіграють важливу роль у процесі демократизації політичної системи, але їх не слід перебільшувати, оскільки вони не можуть самостійно сприяти процесам трансформації, а на початкових етапах процесу демократизації каталізатором може бути за винятком поєднання з внутрішніми тенденціями розвитку (2004, с. 69-70). У науковій літературі прийнято розрізняти два основні підходи до аналізу проблем демократизації. Перший підхід спирається на аналіз структурних факторів транзиту демократії, причому найбільше значення надається вивченню умов, соціально-економічних вимог та культурної цінності, які перешкоджають або сприяють встановленню та консолідації демократичних норм та інститутів. У другому підході дослідники аналізують процесуальні фактори процесу демократизації (особливості та послідовність рішень та конкретних дій, що реалізуються обмеженою кількістю ініціаторів та учасників процесу демократизації) (Мельвиль, 2007, С. 132-134).

Наприкінці 1950-х С. Ліпсетт припускав, що чим вище в країні рівень економічного розвитку (рівень ВНП на душу населення, якість освіти, ступінь урбанізації, індустріалізація тощо), тим сприятливіші умови для демократичного управління. Але на початку 1990-х, аналізуючи процеси демократизації у 113 країнах, він зробив висновок, що високий рівень економічного розвитку за певних обставин сприяв лише демократизації політичних інститутів (Липсет, Кен-Рюн та Торрес, 1993). 
Дійсно, завдяки великим дослідженням у цій галузі, можна зазначити, що високі темпи економічного зростання можуть бути лише необхідною умовою демократизації 3 точки зору створення соціальної бази для демократичних переходів. Тому Р. Інглхарт, Г. Алмонд та С. Верба назвали культурні та ціннісні умови ключовими для демократичного розвитку. На їхню думку, найважливішою передумовою демократизації $\epsilon$ існування цінностей та поглядів у суспільстві, пов’язаних із громадянською культурою (особиста довіра, підтримка демократичних інститутів, політична участь, відповідальність, толерантність) (Инглхарт, 1997). Демократію можна зберегти і розвинути лише шляхом розвитку цих компонентів серед широкої громадськості. Цінності та орієнтації «громадянської культури» створюють сприятливий клімат для стабільної та стійкої демократії та значно полегшують демократичний транзит. Однак демократизація можлива за відсутності їх всебічного розповсюдження (Алмонд и Верба, 1997).

Іншою національною умовою демократії $\epsilon$ національна єдність та відповідна ідентичність, найменш сумнівний аспект, який майже не критикується в сучасній науковій літературі. Історія показує, що проблема національної єдності повинна бути вирішена або поставлена на місцевому рівні та поставлена в чіткі правові рамки до початку демократизації (Крюкова, 2014). Націоналізм, який є результатом невирішених національних проблем, стає головною перешкодою для демократизації та конфліктів 3 демократією. Однак важливо враховувати, що ресурс єдності та національної ідентичності, а також культурний компонент демократизації не є однорідним і впорядкованим назавжди. Він складається 3: психологічних особливостей нації (деякі культурні традиції, специфічні історичні особливості національної свідомості, системи міфів, вірувань тощо), особистісні можливості політичного лідера та здатність правлячої еліти формувати та поширювати прийнятну для суспільства та основних верств населення ідеологію та підтримувати іiі (Цыганков, 1995, с. 96-115). Ці компоненти повинні бути в збалансованому стані та свідчити про прагнення досягти 
загальних цілей. Тільки в цьому випадку можна розраховувати на побудову стабільної та стійкої демократії та успіх демократичних перетворень. Прихильники процесуального підходу виходять із принципово іншої позиції в аналізі процесів демократизації. Дж. Шумпетер, наприкінці 40-х років, розглядав демократію як форму правління, що заснована на виборчій конкуренції. Регулярне проведення вільних і чесних виборів, на його думку, $є$ мінімальним критерієм для демократії та важливим фактором демократії (Шумпетер, 1995, с. 314).

У цьому випадку єдиним можливим механізмом досягнення та підтвердження владних ресурсів, що встановлюють чіткі рамки для всіх елітних груп, i, таким чином, об’єднуючи елітну структуру та створюючи ефективні можливості для спілкування та інтеграції влади та суспільства, є виборчі процедури.

У 1970-х pp. Р. Даль (2002) використав два показники для аналізу процесів демократизації - змагальність акторів та участі громадськості. Високі стандарти цих стандартів сприяють створенню «багатосистемної системи» - такої, яка значною мірою відповідає демократичним ідеалам. Американські транзитологи Т. Карл та Ф. Шміттер визначають різновиди варіантів демократичних переходів у країнах Південної та Східної Свропи, Латинській Америці, два основні параметри як основу для класифікації: домінуючий тип акторів (еліта чи маси) та основні стратегії до яких вони вдаються (сила чи компроміс). Вони пропонують чотири моделі трансформації, засновані на суміші дійових осіб та стратегій: пакт, реформа, революція та нав’язана трансформація (Karl and Schumitter, 1991). Автори класифікують ці моделі за рівнем невизначеності, зазначаючи, що вона $є$ мінімальна у випадку елітарної угоди (пакту еліт), а максимальна у контексті революції та нав’язаній трансформації. Підходи, засновані на абсолютизації деяких факторів (структурних чи процедурних за своєю суттю) при вивченні процесів демократизації, не дають бажаних результатів. Важко знайти загальні глобальні причини глибокого розуміння рушійних сил 
демократичного транзиту. Часто прагнення дослідників визначити конкретні закони формування демократії призводило до пошуку загальних основ (економічних, соціальних, політичних тощо), однак історичний та культурний контекст часто ігнорували. А. Мельвіль представляє у своїй праці «Демократичний транзит: теоретичні, методологічні та прикладні аспекти» багатофакторну модель демократичного аналізу транзиту, яка є продуктивною і відповідає всім вимогам сучасних тенденцій розвитку суспільства та держави. Багатовимірність процесу демократизації вирішує проблему аналізу складових компонентів демократичної транзитної структури, що дає змогу оцінити іï ефективність. Таким чином, головним показником тут є політичні інститути та процеси, їх трансформація, в основі тенденції структуризації партійної системи і всебічний аналіз побудови та складу державних інститутів та виборчої системи (Мельвиль, 2007, с. 132134).

Визначене таким чином поняття «демократія» має два аспекти: конкуренція та участь. Сучасна демократія - це демократія національної держави та їі виникнення тісно пов’язано з розвитком останнього.

В Україні можна дотримуватися багатьох принципів, притаманних демократичним суспільним і політичним відносинам зарубіжних країн, однак ментальні ознаки та національні особливості стають перешкодою для їх застосування на практиці (ігнорування та недотримання правил та вимог законодавства України, відсутність активної позиції влади та невиконання пріоритетних завдань), що викликають хаос та плутанину (Куц, 2018). Для вдосконалення процесу демократизації суспільно-політичних відносин в Україні необхідно розвивати та стимулювати формування ключових демократичних цінностей, таких як: професіоналізм керівників урядів на різних рівнях влади; пристойність представників держави та громадян; нейтралітет; групове керівництво з урахуванням потреб та запитів громадян; ефективність; підзвітність гілок влади; орієнтація на соціальні потреби країни з урахуванням минулого історичного досвіду; відкрита, прозора, 
некорумпована та соціально орієнтована система політичних відносин (Фесянов, 2017).

Висновки та перспективи подальших досліджень. Демократизація політичного життя - це не просто визнання людей джерелом політичної влади, або затвердження загального виборчого права на рівних умовах, поява багатопартійної політики або декларування політичних прав та основних свобод громадяни. Демократизація визначає стан духовної свободи індивіда, міру творчості та розкриття можливостей. Духовне відродження суспільства в умовах демократії - це багатогранний процес формування духовної культури, заснований на акценті в суспільстві принципів та ідеалів демократичного змісту, що створює можливість для вільного розвитку всіх культур, типів, орієнтацій та форм представлених в цьому суспільстві. Це тенденція до загальнолюдських цінностей та специфіки ii проявів у національній своєрідності, що забезпечує духовний процес та глобальний розвиток.

Таким чином, слід зазначити, що наявність демократичних інститутів не є гарантією демократії. Необхідно проаналізувати функції та ефективність цих інститутів. На наш погляд, демократією є лише такий політичний устрій, який несе в собі властивості ліберальної демократії, а саме їі базові принципи стають основою демократизації суспільства.

\section{ЛІТЕРАТУРА}

1. Алмонд, Г. и Верба, С. 1997. Гражданская культура и стабильность демократии. Антология мировой политической мысли. Т.2. Москва: Мысль.

2. Грачев, М.Н. и Мадатов, А. С. 2004. Демократия: методология исследования, анализ перспектив. Москва: АЛКИГАММА.

3. Даль, Р., 2002. Предпосылки возникновения и утверждения полиархий. Полис, 6, с. 34-57.

4. Инглхарт, Р., 1997. Постмодерн: меняющиеся ценности и изменяющееся общество. Полис, 4, с. 18-28.

5. Крюкова, Е. В., 2014. Демократизация: факторы и результативность. Власть. 22(12), c. $97-100$.

6. Куц, Г. М. 2011. Ліберальні трансформації політичного простору: монографія. Харків. 
7. Куц, Г. М., 2018. Влада і суспільство в постмайданній Україні: діагностика відносин. Наукові записки Інституту політичних і етнонаціональних досліджень ім. І. Ф. Кураса НАН України, [online] 2. с. 159-171. Доступно: http://nbuv.gov.ua/UJRN/Nzipiend_2018_2_13 [Дата звернення 1 лютого 2019]

8. Липсет, С., Кен-Рюн С. и Торрес Д., 1993. Сравнительный анализ социальных условий, необходимых для становления демократий. Международный журнал соичальных нау, 3, с. 5-34.

9. Мельвиль, А. Ю. 2007. Демократические транзиты. Политология. Москва: РОССПЭН.

10. Пшеворский, А., 1993. Переходы к демократии. Путь, 3, с. 3-56.

11. Фесянов, П.О., 2017. Зарубіжний досвід демократизації суспільно-політичних відносин. Інвестииї: практика та досвід, 20, с. 59-62.

12. Цыганков, А. П. 1995. Современные политические режимы: структура, пипология, динамика. Москва: Интерпракс

13. Шумпетер, И., 1995. Капитализм, социализм и демократия. Перевод с английского В.С. Автономова. Москва: Экономика.

14. Хантингтон, С., 2003. Третья волна: Демократизащия в конще XX века. Москва: РОССПЭН.

15. Karl T. and Schumitter P., 1991. Models of Transition in Latin America, Southern and Eastern Europe. International Social Science Journal, 128, pp. 269-284.

\section{Інформація про автора}

Застава Ірина Валентинівна - кандидат політичних наук, доцент кафедри міжнародних відносин, міжнародної інформації та безпеки, факультету міжнародних економічних відносин та туристичного бізнесу Харківського національного університету імені В.Н. Каразіна; e-mail: i.v.zastava@karazin.ua; ORCID: http://orcid.org/0000-0002-7604-8823.

Стаття надійшла до редакції: 07.03.2019 р. $\quad$ Прийнята до друку: 22.03.2019 p. 